\title{
HISTOLOGICAL EFFECTS OF THIAMETHOXAN INSECTICIDES ON MIDGUT OF HORNET WORKERS VESP ORIENTALIS L. (HYMENOPTERA: VESPIDAE).
}

\author{
SAeEd HAmmo AmeEn and TAlal TAher Mahmoud \\ Dept. of Plant protection, College of Agriculture Engineering Sciences, University of Duhok, \\ Kurdistan Region-Iraq
}

(Received: May 31, 2020; Accepted for Publication: June 28, 2020)

\begin{abstract}
Oriental hornet is one of the main pest to beekeeping in Iraq and other countries. Also considered as agricultural pest. Adults of Oriental hornet workers were treated with three different concentrations (7500, 5000 and 2500) $\mathrm{mg} / 4 \mathrm{ml}$ (distilled water) from the insecticide Thiamethoxam 10\%. The results showed slight changes in the midgut of adult wasps workers who were exposed to a minimum concentration of 2500 $\mathrm{mg} 4$ / $\mathrm{ml}$ distilled water. And the workers exposed to lethal concentration $5000 \mathrm{mg} / 4 \mathrm{ml}$, exhibit less morphological alterations in the epithelium cells of midgut; cytoplasmic vacuoles, deformation of digestive cells with overlapping, disorganizing of nucleus, cytoplasmic protrusions and microvilli observed on the apical part of epithelium cells. Whereas, the Oriental hornet workers were exposed to excessive concentration which was $7500 \mathrm{mg} 4 / \mathrm{ml}$, caused severe changes in the midgut epithelium cells compared with previous doses: uncondensed cytoplasm, nucleus elongated and shrinkage, blebs with appearance of nucleoli scattered and releases into the cytoplasm, regions with cytoplasmic vacuolization, ruptured and breaks of apical cell membrane from the top with release of cell contents into the lumen, and the nucleus condensing with pyknosis of nuclei are observed.
\end{abstract}

KEYWORDS: Toxicity; Histology ; Oriental hornet ;Neonicotinoid; Midgut

\section{INTRODUCTION}

Vespa orientalis, Oriental Hornet is eusocial insects belong to Hymeno-ptera Family vespidae, Oriental Hornet considered a main pest to honeybee in many Arab countries as Egypt, Iraq, Saudi Arabia, Oman, Palestine, Lebanon, Emirate, Jorden, Yemen, Sudanand, and Syria. (Abdelaal, and EL-defrawy,2014.), (Khodairy, and. Awad, 2013), and (Glaiim, 2009).Also count as an agricultural pest that cause damages to fruit trees, grapes, figs, and Vegetables. (Glaiim, 2009.) (Abdelaal,. and ELdefrawy, 2014.) (Al-Mahdawiand. and AlKinani, 2011) and (Spurr, 1991). Oriental hornets with their powerful sting can cause hurting and mortal reaction in case of allergic person get sting (Tawfiq et al., 2016).

In many countries as well as Iraq beekeepers have trained many method developed by the beekeepers them-selves to control all the species of the genus Vespa (Al-Mahdawiand. and AlKinani, 2011). Killing of queen of vespa orientalis in the beginning of spring to get rid of many of would be enemies in the summer and autumn, and hornets nests damage by applying insecticides or fire after dark; furthermore baited and non-baited traps. Although these methods are operational, while they are tedious and expensive, (Glaiim et al., 2008).

The first line of resistance against extreme level of insecticides and metals in the insects are the midgut cells. This study is concentrated on investigating for morphological characteristics of midgut cell that might be significant for the circulation of metals or their elimination, therefore defending the insects against their toxicity (Rost- Roszkowska., et al, 2008). The epi-thelium of midgut is primarily consist of the epithelial and regenerative cells. The epithelial cells are responsible for the food digestibility through the manu-facture and secretion of enzymes and absorption of digests. The second group of cells found among basal areas of epithelial cells exchanges them when they are 
missing as result of scratch or getting old processes (Cavalcante and Cruz-Landin 1999).

Very little scientific literatures on the effect of insecticides on the midgut cells of the Oriental hornets, has been done (Elbert et al., 2008; and Matsuda et al., 2001) reported that among the various kinds of insecticides the neonicotinoids including amidacloprid, acetamiprid, thiacloprid and thiame-thoxam that work as an agonist of nicotinic acetylcholine receptors of insects, Thus considered important group ofneurotoxins. Neonicotinoids insecticides are widely used in agriculture specially against sucking insects.

The Midgut is one of the main organs for toxicity analysis, as it is in control for digestion and absorption of digest food; Furthermore it is one of the major source of interaction when insects comes in contact with insecticides orally (Catae et al., 2014). The midgut cells alterations caused by insecticides demonstrated by some investigators (Cruz et al., 2010; Ferreira et al., 2013; Jesuset al., 2005; Oliveira et al., 2013, Rossi et al., 2013). The aim of this study is to detect the physiological and morphological alterations in the midgut cells which is responsible for absorption and digestion of food using histological techniques and light Microscopy by exposure hornet's adult workers to different doses of thiamethoxam $10 \%$ insecticide.

\section{MATERIAL AND METHODS}

\subsection{Oriental Hornet Collecting Methods}

Wooden Traps, using cages made of wood (50 x35 cm) cover with metal screen with small conical hole at the bottom (Abdelaal and ElDefraw, 2014) .Different baits such as sheep meet, bee food (Candy), and Sardin fish were used for attracting wasps.

- Net collecting, Aerial collecting nets which is made of a circle of metal wire diameter $30 \mathrm{~cm}$ cover with muslin and connect with wooden stick length $100 \mathrm{~cm}$. workers were collected placed in the plastic bottles 1.5 liter already contain holes for air exchange then moving to the growth chamber.

- Collection by aerial net and special boxes, the most effective way to collect wasps. Near pools of water, running water, spring water, and near the apiaries of honeybees, where the Oriental hornets gather, the wasps were collected by aerial net and then transported to special cages (50x35 $\mathrm{cm}$ ), made of wood and a metal mesh that covers three faces while the other side is closed with a wooden board that has a small door with a slide to open and close at the bottom $(12 \times 8 \mathrm{~cm})$, to provide food and water; in addition to the main door at the top. When many wasps meet, the wasps were covered with a net and then about 1025 hornet workers gathered simultaneously, transported to the cages by making the box inverted, so that the main door would be down in an attempt to fit the mesh opening with the upper door of the cage(Fig.1),

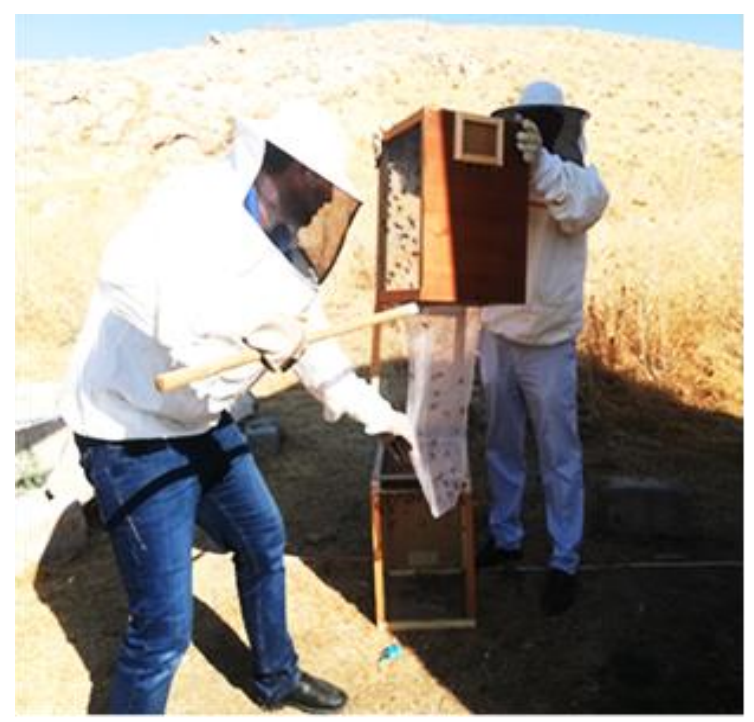

Figure 1. Collection by aerial net and special boxes

\subsection{Method of Rearing:}

Nests collecting, three nest where collected from different places Besifki and Sinjar and they were placed in the growth chamber Lab. at (29 $\pm 1 \mathrm{C}^{\circ}$ ) and relative humidity $67 \% \pm 1$, with in the cages $(35 * 35 * 50 \mathrm{~cm})$ provide with bee food (Candy) through the small (Fig. 2).

\subsection{Fixation and Insects Treatments}

Pick up 40 Adult workers of Oriental hornets aged 7 - 40 days at random from stock culture by cooling them for 8-10 minutes at $8 \mathrm{C}^{\mathrm{o}}$. Hornets wasps where placed in four disposal cages $(15 \times 15 \times 15 \mathrm{~cm})$ for each ten workers and exposure to three concentrations of thiamethoxam $10 \%$ (Agita insecticides) over lethal concentration $7500 \mathrm{mg} / 4 \mathrm{ml}$ distilled water spread out on the $166 \mathrm{~g}$. of bee food (Candy) for first group, and lethal concentration $5000 \mathrm{mg} / 4 \mathrm{ml}$ distilled water spread out on the $166 \mathrm{~g}$.

of bee food (Candy) for second group, then sub-lethal concentration $2500 \mathrm{mg} / 4 \mathrm{ml}$ distilled water spread out on the $166 \mathrm{~g}$. of bee food (Candy) for third group, and fed the control with bee food (Candy) and H2O 1:1, dead workers 
were collected after 24hours and cut off all the appendages, the head and the thorax regions as well. Transfer the abdomen to $100 \%$ alcohol for 2 hours. Placed the Sample into the formalin $10 \%$ for 24-48 hours Tissue processing by passing the samples through formalin $10 \%$ for 90 minutes first, then Ethanol 70\%, \%90, 100\% and 100\% for each 90 minutes. Dehydration of specimens were placed in Xylene for 4-5 hours. (Christopher et al., 2017).

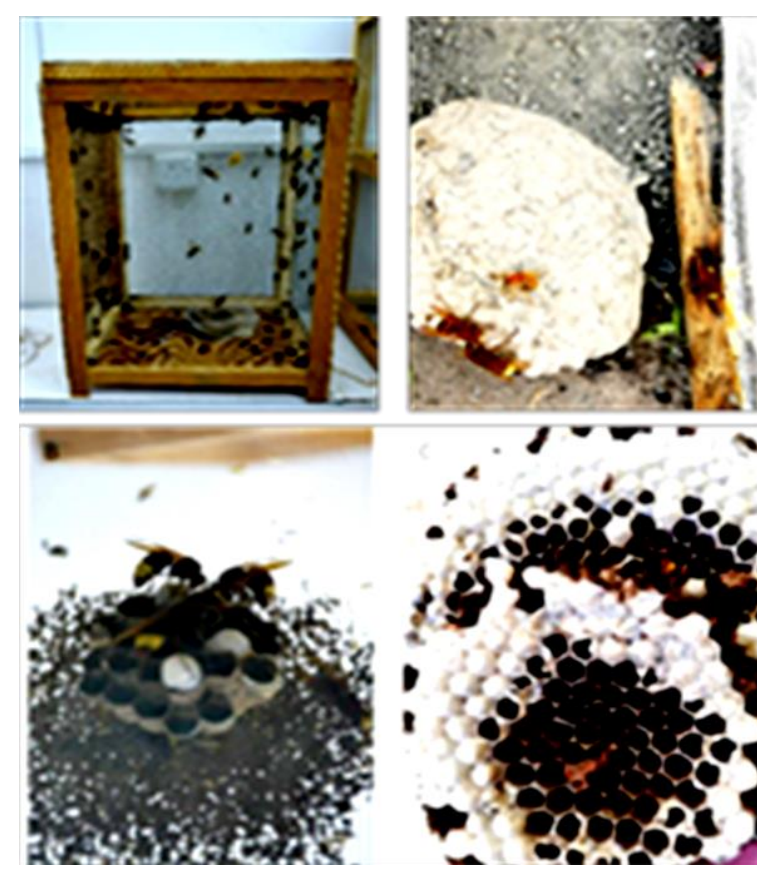

Fig, (2): Hornets rearing cage, Oriental Hornets' nest with brood2.4. Embedding and Cutting
Embedding by Placed the samples into the hot paraffin wax three times for $1.5,1.5,1.5$ hours. $\left(55-60 \mathrm{C}^{\circ}\right.$ ) at $28 \mathrm{C}^{\mathrm{o}}$ (Fig. 3). Cooling the blocks by using the LEICA EG 1130 (Fig.4), to pre-cool the paraffin embedded biological specimen at $-30 \mathrm{C}^{\circ}$ before start sectioning on the Microtome. After cooling process completed the blocks were ready for cutting using Manual Microtome LIECARM2235 (fig. 5), and paraffin sections were collected at 3-5 $\mu \mathrm{m}$ starting from the end of the abdomen. Placed the sections in to water bath at $40 \mathrm{C}^{\circ}$ (Fig. 6). Sections where dewaxed in the xylene for 6 'minutes and drayed using Oven at $60 \mathrm{C}^{\circ}$ for 30 minutes. 


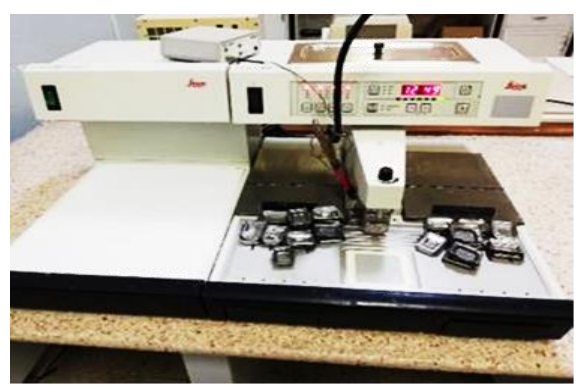

Fig. (3): Specimen where placed in paraffin blocks.

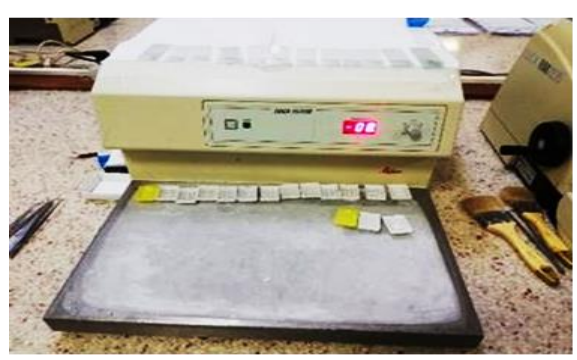

Fig.(4): LEICA EG 1130 to pre-cool the paraffin embedded biological specimen at $30 \mathrm{C}^{\circ}$

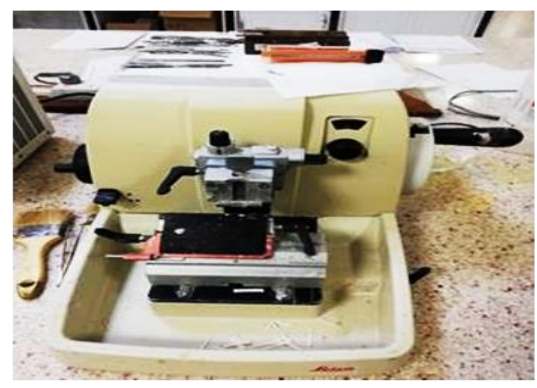

Fig. (5): Manual Microtome LIECARM-2235

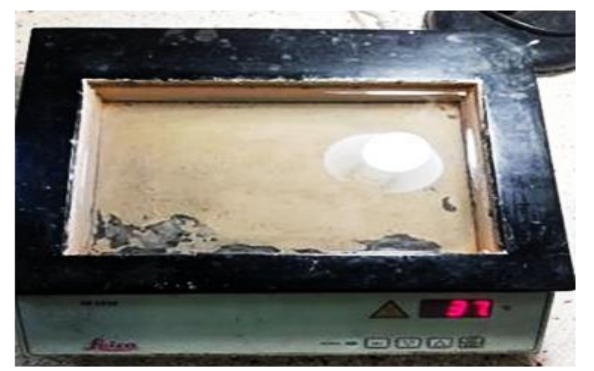

Fig. (6): Water bath

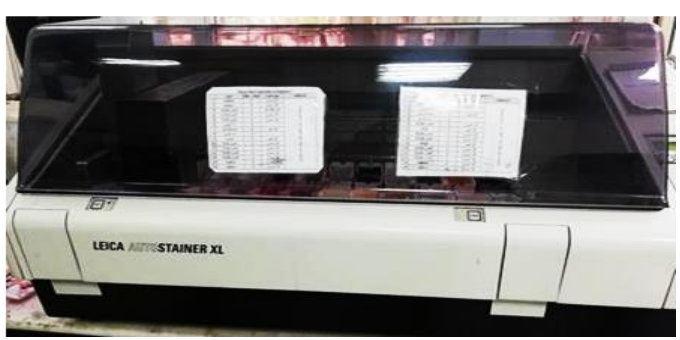

Fig. (7): LEICA AUTOSTAINER XL.

Table( 1): Tissue Staining process

\begin{tabular}{|c|c|c|}
\hline Step & $\begin{array}{c}\text { Substances (solutions } \\
\text { ) }\end{array}$ & Time \\
\hline 1. & Xylene & 3 minutes \\
\hline 2. & Xylene & 3 minutes \\
\hline 3. & Ethanol $100 \%$ & 2 minutes \\
\hline 4. & Ethanol $90 \%$ & 2 minutes \\
\hline 5. & Ethanol $70 \%$ & 2 minutes \\
\hline 6. & Tap Water & 3 minutes \\
\hline 7. & Hematoxylin & 6 minutes \\
\hline 8. & Tap Water & 3 minutes \\
\hline
\end{tabular}

Part of M.Sc.for $1^{\text {st }}$. Author
Tissue Staining process were carried out using LEICA AUT-OSTAINER XL, (Fig.7).As show in the (table 2) Cover the slides with DPX and left to be dray $20-30$ minutes, then the sections were examined using (Microscope Olym-pus CX 22 RFS1, China) under magnification $40 \mathrm{X}$ and 100X, then the Microphotographs were taking with (NIKON DIGITAL CAMERA D 5200, U.S.A). 


\begin{tabular}{rcc}
\hline 9. & Eosin & 3 minutes \\
\hline 10. & Ethanol $70 \%$ & 2 minutes \\
\hline & Ethanol $90 \%$ & 2 minutes \\
\hline 11. & Ethanol $100 \%$ & 2 minutes \\
\hline 12. & Ethanol $100 \%$ & 2 minutes \\
\hline \multicolumn{3}{c}{} \\
\hline 13. & Xylene \\
\hline & 5 minutes \\
\hline 15. & Xylene \\
\hline
\end{tabular}

\section{RESULTS}

In this study the sections were examined under the microscope, oriental hornet's midgut from control group revealed typical characteristics of this structure: longitudinal muscles regenerative cells, goblet cells and columnar cells with nucleus of spherical shape with no alterations in the cell organelles and cytoplasm (Fig. 8. A, B, C).

In the experimental group that treated with high lethal dose $7500 \mathrm{mg} / 4 \mathrm{ml}$ distilled water and after 24 hours of treatment. The midgut cells exhibit irregular structure and uncondensed of cytoplasm, nucleus elongated shrinkage initiation of blebs at the apical of epithelium with appearance of nucleoli scattered and releases into the cytoplasm, the epithelium of midgut show severe decrease in the thickness and show many cytoplasmic vacuolation regions Fig. (9. A, B and C). Then the epithelium cells start swelling, ruptured and break of apical cell membrane from the top with release of cell contents into the lumen, and the nucleus condensing with pyknosis of nuclei are observed Fig. (9. D, E).

In the wasps groups exposed to a concentration equivalent to $5000 \mathrm{mg} / 4 \mathrm{ml}$ distilled water of thiamethoxam. The midgut cells exhibited cytoplasmic vacuolization and deformation of digestive cells with overlapping, and the disorganizing of nucleus and cytoplasm with protrusions and microvilli observed on the apical part of epithelium cells Fig. (10. A, B and C).

The third group of Oriental hornets were treated with sub-lethal dose $2500 \mathrm{mg} / 4 \mathrm{ml}$ distilled water of thiamethoxam $10 \%$ insecticide, and the sections were examined under the microscope, the midgut cells showed swollen vacuolated, less midgut epithelium, and the cytoplasmic protrusions in the apex of epithelium cells with no microvilli are observed, also exhibit row of condensed nucleus and reduction in the number of regenerative cells with very obvious fragmentation of midgut epithelium on the top of folded regions as show in (Fig.11. A and B). 


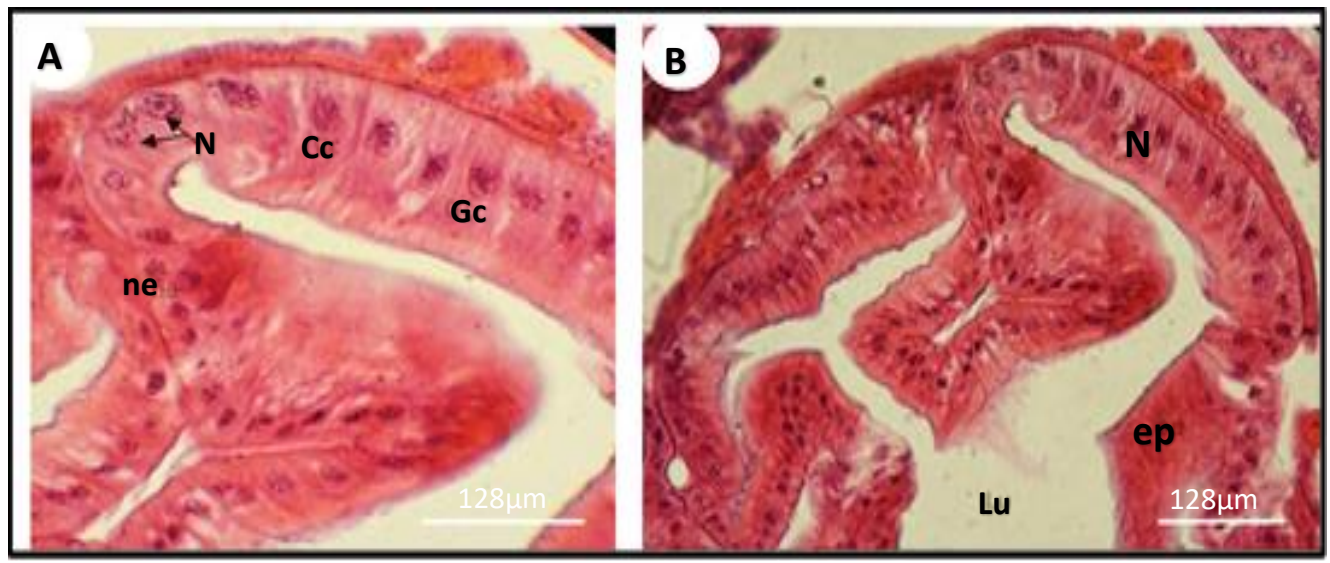

$128 \mu \mathrm{m}$

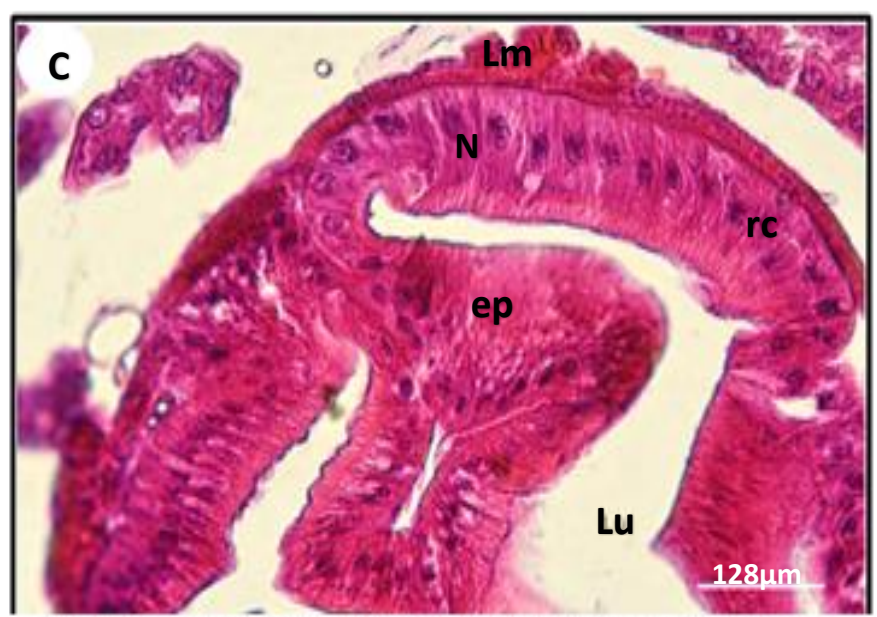

Fig. (8): Histological sections $(3-5 \mu \mathrm{m})$ through midgut of Vespa orientalis $L$. workers control group. (A) Midgut epithelium cells showing columnar cells $(\mathrm{Cc})$.Goblet cells( $\mathrm{Gc})$.with large spherical nucleus(N) where nuclei (ne)of epithelial digestive cells are observed.(B and $\mathrm{C}$ ) Showing midgut epithelium detail(ep),and showing longitudinal muscles in the outside with circular shape $(\mathrm{Lm})$, and the lumen(Lu), Digestive cell $(\mathrm{Cc})$, with spherical organizing Nucleus(N) including some nuclei(ne).and goblet cells $(\mathrm{Gc})$ arrange around with regenerative cells (re) between columnar and goblet cells are observed. 

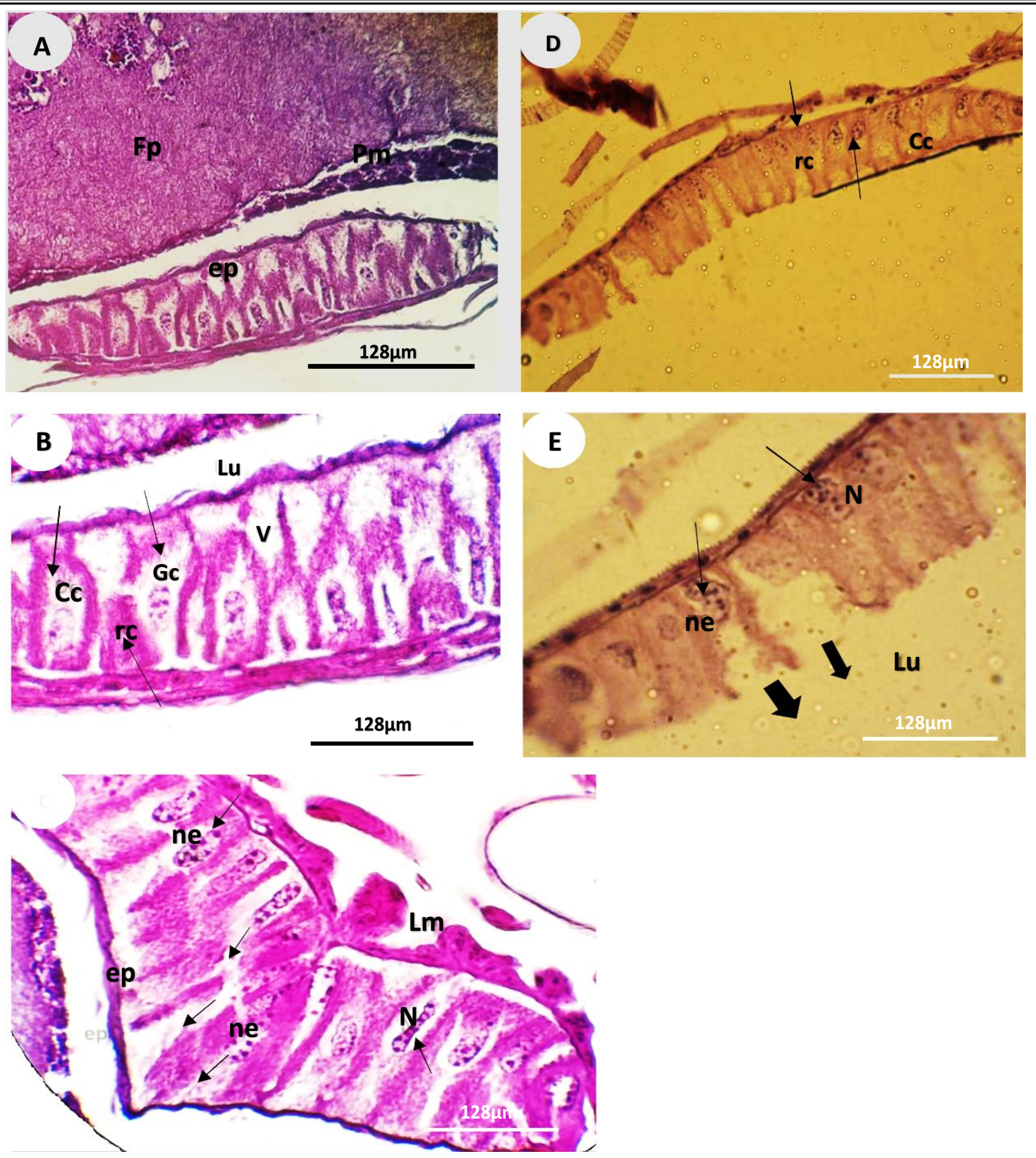

Fig. (9): Histological sections and microphotographs of midgut of Vespa orientalis L. adult workers $(3-5 \mu \mathrm{m})$ treated with over-lethal dose of thiamethoxam $10 \%, 75000 \mathrm{mg} / 4 \mathrm{ml}$. (A) Midgut epithelium show irregular structure with and uncondensed cytoplasm (ep),food particle(Fp), peritrophic membrane(pm). (B and C ) Midgut cells, digestive cells $(\mathrm{Dc})$, regenerative cells (rc), and goblet cells(Gc) showing nucleus elongated, shrinkage and blebs with appearance of nucleoli (ne)scattered and releases into the cytoplasm, and epithelium (ep) showing decrease in thickness with cytoplasmic vacuolization(V).(D and E) Epithelium cells start swelling, ruptured and break of apical membrane( )from the top wh release of cell contents in to the lumen $(\mathrm{Lu})$, and the nucleus condensing with Pyknosis of nuclei are observed. 

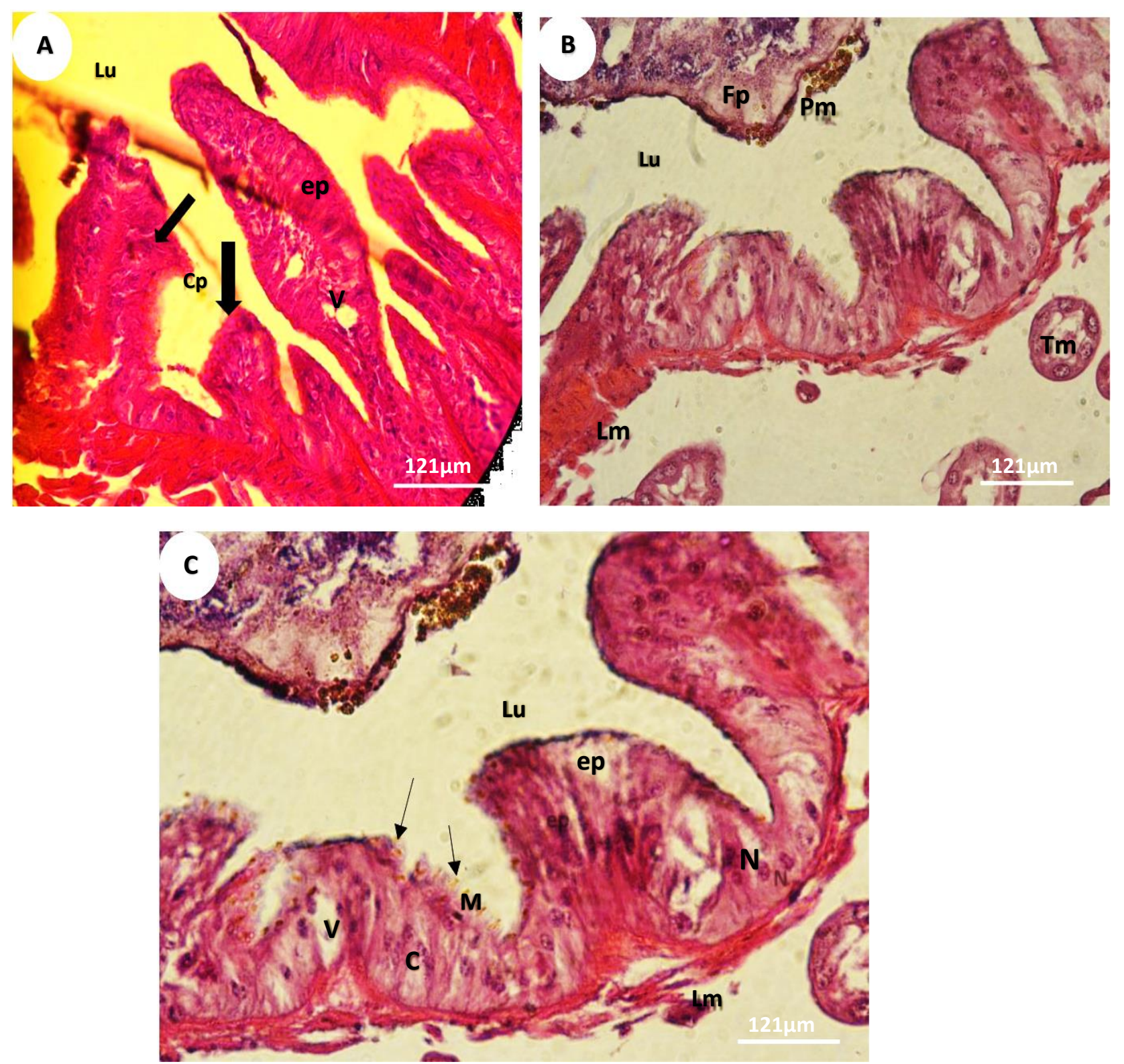

Fig. (10):Histological section through the midgut of Vespa orientalis $(3-5 \mu \mathrm{m})$ bar $=121 \mu \mathrm{m}$, showing effects of Lethal Dose of thiamethoxam $10 \%$ insecticide $5000 \mathrm{mg} / 4$ ml.(A)The Lumen (Lu)and the midgut epithelium showing cytoplasmic protrusions( Pc $\downarrow \downarrow$ )with cytoplasmic vacuolization(V). (B) Peritrophic membrane (Pm) surrounding food particle (Fp) and Malpighian tubules(Tm). (C) The Lumen (Lu) and the midgut epithelium (ep) exhibit condensed cytoplasm and dislocate Nucleus (N), with microvilli $(\mathrm{M} \downarrow \downarrow)$, cytoplasmic vacuolization (V), and disorganizing cells (c). Longitudinal muscles from outside (Lm). 

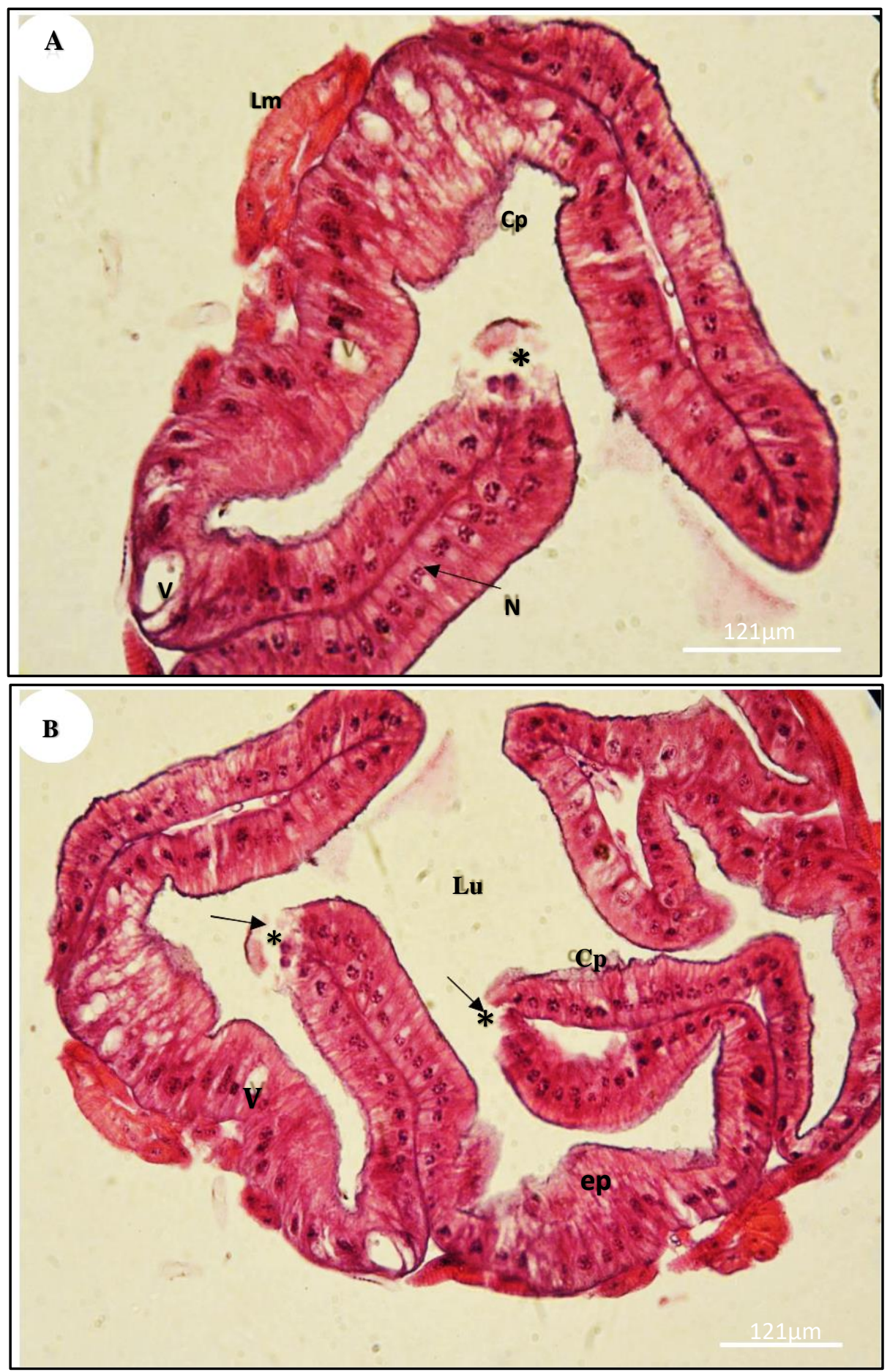

Fig. (11): Histological sections through midgut of Vespa orientalis $(3-5 \mu \mathrm{m})$ exposed to sub-lethal dose of thiamethoxam $10 \%$ insecticide. (A and B) Show swelled vacuolated cytoplasm (V) in epithelium cells with less midgut epithelium (ep) and the cytoplasmic protrusions (cp) in the apex of epithelium cells(ep) with no microvilli are observed, also exhibit reduction in the number of regenerative cells with very obvious fragmentation (*) of midgut epithelium on the apical of folded regions with row of condensed nucleus $(\mathrm{N})$. 


\section{DISCUSSION}

The present study results support the significance of using Toxicology bioassay joined with morphological examination of tissues and organs of oriental hornets exposed to chronic doses of commercial insecticides. Bioassay in vitro investigated that thiamethoxam $10 \%$ dramatically decreases the lifespan of hornet workers regardless of the concen tration, while the different level of degradation and alteration between two doses has been used demonstrated by morphological data, which was more obvious in the hornets midgut. (Sumida, 2010).

In this study our results indicated that the treatment of Oriental hornet works with diet containing thiame thoxam $10 \%$ with three different Concentrations exhibit severe morpho logical and structural alterations in the midgut epithelium particularly was observed in the treatment of over lethal concentration $7500 \mathrm{mg} / 4$ $\mathrm{ml}$ treatment followed by the concentration 5000 $\mathrm{mg} / 4 \mathrm{ml}$, and less alteration in the wasps workers treated with the concentration $2500 \mathrm{mg} / 250 \mathrm{ml}$ (Sumida, 2010) and (Catae, 2014).

According to (Cruz-Landim, 2009) the midgut is responsible for most of the digestion and absorption of food which is part of digestive system and is considered the practical stomach in insects. Because the orally insecticides was conducted, therefore one of the first locations to come in the contact with the insecticides was the midgut, and the midgut suffered direct effects at the beginning of the treatment. In Vespidae midgut three kinds of enzymes can be found that play a role in the detoxification process: cytochrome $\mathrm{P} 450 \mathrm{~s}$, glutathione $\mathrm{S}$ transferases, and carboxylesterases. These enzymes implement the process of biotransformation of chemical substances, so the reaction of these enzymes with insecticides produce alterations in the epithelium of midgut (Yu, et al., 1984).

The midgut cells, exhibits irregular structure, uncondensed of cytoplasm, the nucleus elongated shrinkage, blebs with appearance of nucleoli scattered and releases into the cytoplasm, in agreement with (Silva-zacarin, 2007) and. (Oliveire , 2013). The epithelium of midgut showed severe decrease in the thickness and reduction in regenerative cells number in the epithelium, with many cytoplasmic vacuolation regions this results demonstrated in other studies (Oliveire, 2013) and (Catae, 2014).

Also Epithelium cells start swelling, ruptured and break of apical membrane from the top with release of cell contents into the lumen, and the nucleus condensing with pyknosis of nuclei are observed, similar process to that observed in the Attas-exdensrubr-O. (Proskuryakov, 2003), and these results agreed with an Epilachnac $f$. nylanderind (Rost-Roszkowska, 2008) and (Santorum., et al 2019).

The results of treatment Oriental hornet workers with sub-lethal dose $2500 \mathrm{mg} / 4 \mathrm{ml}$ showed less morpho-logical alterations in the midgut epithelium than the over lethal and lethal doses of thiamethoxam $10 \%$. Vacuolated swelled columnar cells, and many intercellular spaces between midgut cells and reduction in the number of regenerative cells with very obvious breakup of midgut epithelium at the apex of folded regions, the very similar results documented in the Africanized Aipsmellifera by (Oliveire RA., 2013), and (Catae,2014). Cyto plasmic protrusions in the apex of digestive cells with no microvilli are observed, unlike the second group treated with lethal dose which was microvilli has been seen very clear, and very locate of spherical nucleus similar to control group.

In conclusion treatment with low concentrations of the thiamethoxam $10 \%$ occur physiological effect in the midgut of hornet's workers when it is administrated for short time $(24 \mathrm{~h}$.) causes an the destructive effects of midgut by ultrastructural and mor-phological alterations harms to these tissues, and significantly affects the absorption and digestion processes. However, rising the concentration caused chronic histological alterations in the midgut of Oriental Hornet and this indicate that thiamethoxam is very effective, when orally administrated against wasps workers.

\section{REFERENCES}

Part of M.Sc.for $1^{\text {st }}$. Author 
- Abdelaal, A.A.A. and El-defrawy B.M. (2014). Effcacy of new designed trap for controlling the oriental hornet (Vespaorientalis) in Egyptian apiaries and its measure ments. International journal of Advanced Research, 29(10): 1-8.

- Catae, A. F., Roat, T. C., De Oliveira, R. A., Nocelli, R. C., \&Malaspina, O. (2014). Cytotoxic effects of thiamethoxam in the midgut and malpighian tubules of Africanized Apis mellifera (Hymenoptera: Apidae). Microsc Res Tech, 77(4), 274-281. doi: 10.1002/jemt.22339.

- Al-Mahdawy, Q. H. A and AlKinani, M. A. (2011). Economical damage of the red wasp vespa orientalis grapes. Diyala Agri-cultural Sciences journal, 3(2): $216-222$.

- Cavalcate, V.N., and Cruz Landim, C. (1999). Types of cells present in the in the midgut of insects: reviews. Naturalia (Rio Claro), 24: 19-14.

- Cruz AS, Silva- Zacarin ECM, Bueno O.C.MalaspinaO.(2010). Morpho-logical alterations induced by boric acid and fipronil in the midgut of workers honeybee(Apismellifera L.) larvae.CellBio Toxicol 26:165-176.

- Christopher B. Freelance, Laura Leone, Colin R. Anderson and Theresa M. Jones (2017): A method of paraffin sectioning and identification of in dole amines in the brain of insects with a sclerotized cuticle, Journal ofHistotechnology,DOI:10.1080/01478885.20 171335376.

- Ebrahim E. and Carpenter J.M. (2012). Distribution pattern of the hornet Vespa orienalis and $V$. crabro in Iran (Hymenoptera: Vespidae) Zoology in the Middle East, 56:63-66.

- Elbert, (2008). Applied aspects of neonicotinoid uses in crop protection. Pest ManagSci 64: $1099-1105$.

- Ferreira RAC, Silva-Zacarin ECM, Malaspina O, Bueno OC, Tomotake MEM, Pereira AM. (2013). Cellular responses in the Malpighian tubules of Scaptotrigo napostica (Latreille,1807) exposed to low doses of fipronil and boric acid. Micron 26:57-65.

- Glaiim, M.K., (2009). Hunting behavior of the oriental hornet vespa orientalis L., and different behavior of the honeybee, Apismellifera L., in Iraq. Bull. Iraq Nat.Mus, 10 (4):1713.

- Glaiim, M. K., Mahdi, H. A. and Ibrahim, H. A. (2008). Testing the efficacy of some methods recom-mended abroad for controlling the oriental hornets, Vespa orientalis L., attacking honey bee, Apismellifera L. colonies in Iraq. Bulletin of Iraq Natural History Museum. 10(3): 21-27.

- Jesus D,Silva-Zacarin ECM, Malaspina O. (2005). Histological studies in the midgut and Malpighian tubules of Apis mellifera workers treated with boric acid. Braz J MorpholSci 22 (Suppl):168.

- Khodairy, M. M. and Abdelaal, A. A. A. wad, (2013). A study on the sensory structure, in relation to some behavioral ecology of the oriental hornet (Vespa orientalis L.). (Hymenoptera: Vespidae). Life Science Journal, 10(2):127-1215.

- Matsuda, K., Buckingham, S. D., Kleier, D., Rauh, J. J., Grauso, M., andSattelle,D.B.(2001).Neonicotinoids: insecticides acting on insect nicotinic acetylcholine receptors. Trends in Pharmacological Scie nces,22(11),573580. doi:10.1016/s01656147(00)01820-4.

- Oliveira RA, Roat TC, and Malaspina O. (2013). Side-effects of thiame thoxan on the brain and midgut of the Africanized honeybee Apis mellifera (Hymenoptera : Apidae). EnvironToxicol.DOI10.1002/tox.21842.

- Proskuryakov, S. Anatoli G. Konoply-annikov, and Vladimir L. Gabaib (2003) Necrosis: specific form of programmed cells death : Exp. cell .res.283:1_6,doi.10.1016/s00144827(02)00027 7.PMID:12565815.

- Rossi C.A., Roat T.C., Tavares D.A., Socolowski P.C., Malaspina O. (2013). Effects of sublethal doses of imidacloprid in Malpighian tubules of Africanized honeybee Apis mellifera (Hymenoptera: Apidae). Microse Res Tech 76:551-558.

- Rost-Roszkowska, M. P. P. (2008). Degradation of the midgut epithet-lium in Epilachnac $f$.

Part of M.Sc.for $1^{\text {st }}$. Author 
Nylanderi (Insecta, Coccinelidae): apoptosis, autophagy, and necrosis. Canadian. Journal of Zoology, 86, 1179. Sackmann, P.M.

- Rabinovich and Corley J.(2001). Succe ssful removal of German yellow jackets (Hymenoptera: Vespidae) by toxic baiting. Journal of Econ omic Entomology ,94 (4): 811816.

- Sackmann. P. and Corley J. C., (2007). Control Vespula germanica (Hym. Vespidae) population using toxic baits: baitattr activeness and pesti cides efficacy. Journal Applied Entomology, 131(9-10):630 -636. Dio:10.111/j.14390418.2007.01 13 2.x.

- Santorum, M., Costa Brancalhão, R. M., Bittencourt Guimarães, A. T., Padovani, C. R., Tettamanti, G., and Carvalho dos Santos, D. (2019). Negative impact of Novaluron on the nontarget insect Bombyx mori (Lepidoptera:Bombycidae). Enviro-nmental Pollution. doi:10.1016/j. envpol.2019.02.095.

- Spurr. E. B,. (1991). Reduction of wasp (Hymenoptra: vespidae) population by poisonbaiting; experimental use of sodium monofluroacetate (1080) in canned sardine. NewZea- land Journal of Zoology 18:215-222. - Silva-zacarin. (2007). Authophagy and apoptosis cordinate physiological cell death in larval salivary gland of Apis mellifera. E.C.M, 516518.

- Sumida (2010). Toxicological and Histopathological Effects of Boric Acid on Attasexdens rubropilosa (Hymenoptera: Formicidae) Work-ers. Entomological Society of America Journal of Economic Entomology, 103(3):676690.

- Tawfiq M., Al Antary, Bassam N. AlHeyari, and Ibrahim K. Nazer (2016). Evaluation of the Attrac-tiveness of the Oriental Wasp Vespa orientalis L. (Hymenoptera: Vespidae) to Different Bait Traps. Advances in Environmental Bio-logy, 10(12) December, Pages: 1-8.

- Yu S. J, Robinson F. A, Nation J. L. (1984). Detoxication capacity in the honey bee Apis mellifera L. Pestic Biochem Physiol 22:360368 .

\footnotetext{
كارتيكرنا هيستولوجى يا قركهري Thiamethoxam 10\% له سهر كهدي ناقهراست يا كاركهرييّن ستهنگتى روــهـلاتى Vespa Orientalis L.(Hymenoptera: Vespidae).
} 


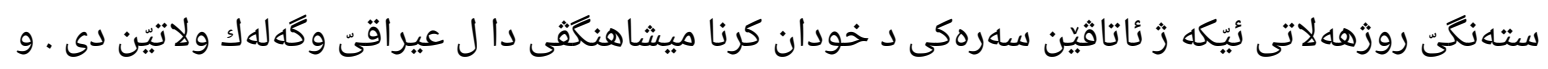

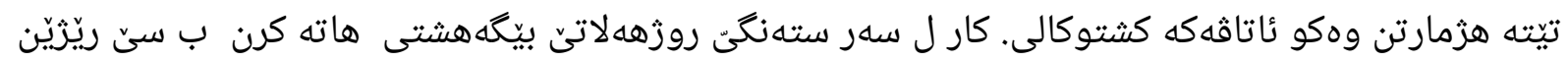

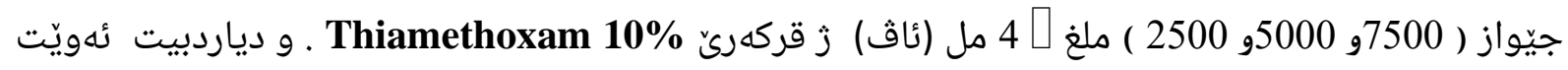

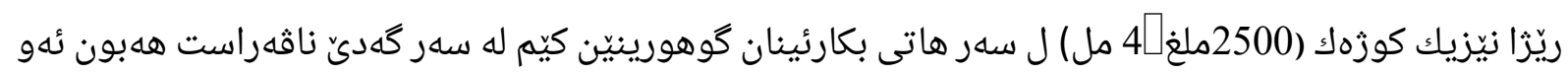

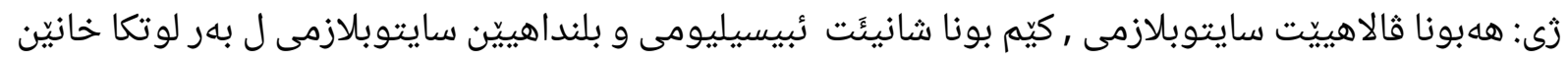

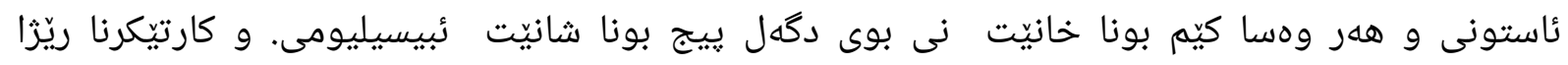

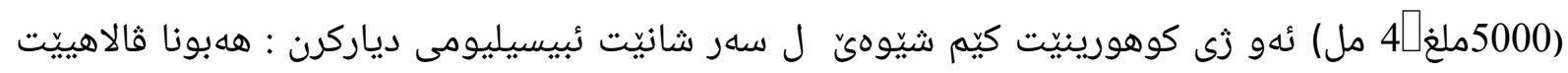

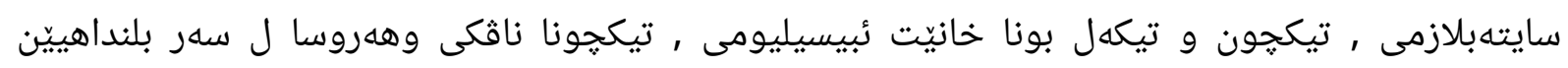

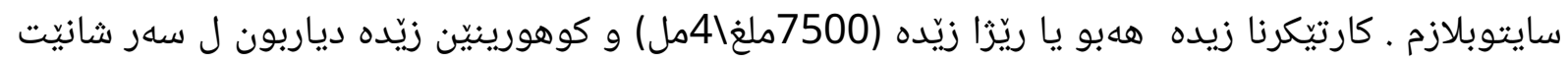

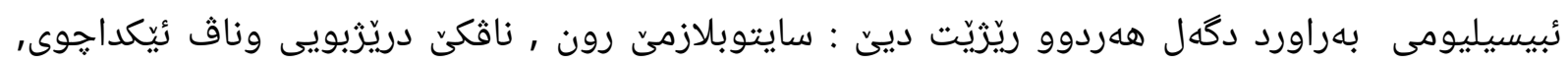

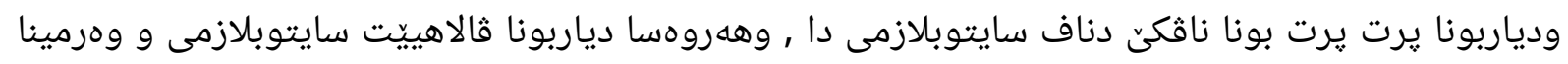

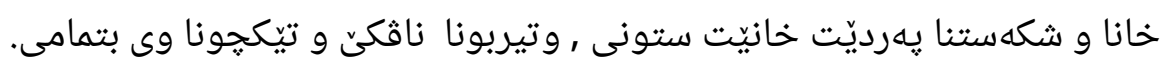

التاثير الهستولوجي للمبيد الحشري Thiamethoxam 10\% في المعي الاوسط لشغالات الزنبور الاحمر

\section{Vespa Orientalis L.(Hymenoptera: Vespidae).}

الخلاصة

الدبور الشرقي هو أحد الافات الرئيسية في تربية النحل في العراق والعديد من البلدان الاخرى. وايضا تعتبر آفة زراعية. تم معاملة بالغات شغالات الزنبور الاحمر بثلاث تراكيز مختلفة ( 7500و (ماء مقطر) من المبيد الحشري Thiamethoxam 10\% وأوضحت النتائج حدوث تغيرات طفيفة في المعي

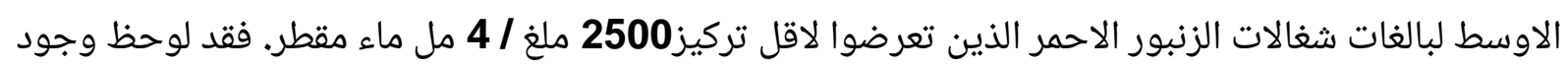

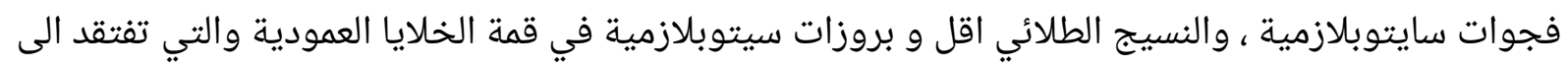

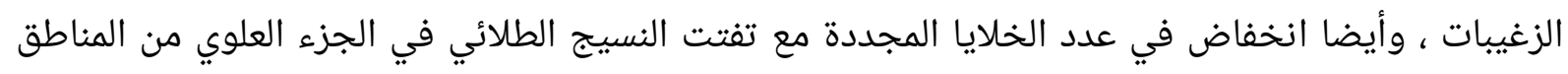

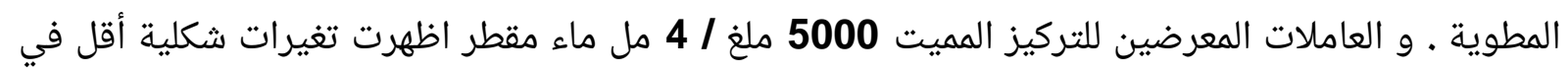
النسيج الطلائي: الفجوات السايتوبلازمية ، تشوه وتداخل الخلايا العمودية ، تشوه النواة ، النتوءات

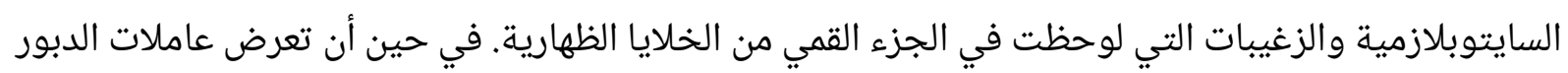

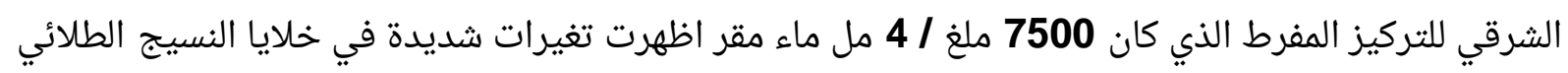

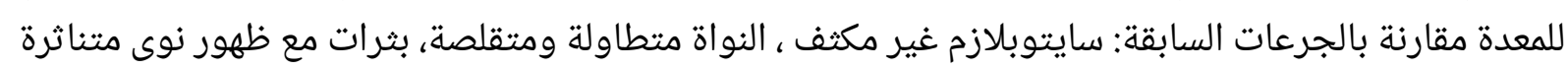
تطلق في السايتوبلازم ، مناطق ذات فجوات سايتوبلازمية ، لوحظ انتفاخ الخلايا و تمزقها ، اضمحلال غشاء الخلية القمي من ألاعلى مع إطلاق محتويات الخلية في التجويف ، ويلاحظ تكثف النواة مع تغلظات في النوى. 